\title{
Production of seven varieties of tomato (Lycopersicon esculentum Mill.) pruned to one and two stems under greenhouse
}

\section{Producción de siete variedades de jitomate (Lycopersicon esculentum Mill.) conducido a uno y dos tallos bajo invernadero}

VARGAS-ESPINOZA, Everardo†, GAYTÁN-RUELAS, Marina, CALDERÓN-RUIZ, Alberto and MORALES FÉLIX, Verónica De Jesús

Universidad Tecnológica del Suroeste de Guanajuato, Carretera Valle-Huanímaro km 1.2. Valle de Santiago, Guanajuato. CP. 38400

ID $1^{\text {st }}$ Author: Everardo, Vargas-Espinoza / ORC ID: 0000-0002-1238-7981, CVU CONACYT ID: 384590

ID $1^{\text {st }}$ Coauthor: Marina, Gaytán-Ruelas / ORC ID: 0000-0002-9714-7628, CVU CONACYT ID: 343244

ID $2^{\text {nd }}$ Coauthor: Alberto, Calderón-Ruiz / ORC ID: 0000-0002-1721-2953, CVU CONACYT ID: 627274

ID $3^{\text {rd }}$ Coauthor: Verónica De Jesús, Morales Félix / ORC ID: 0000-0001-9167-3160, CVU CONACYT ID: 167136

DOI: 10.35429/JANRE.2019.4.3.19.24

Received March 14, 2019; Accepted June 30, 2019

\begin{abstract}
The experiment was conducted from May to August 2018 at the Technological University of the Southwest of Guanajuato (UTSOE) in a randomized complete block design with three repetitions, in greenhouse 1 of $700 \mathrm{~m} 2$ of the Sustainable and Protected Agriculture Career; with the purpose of evaluating the effect of pruning at one and two stems per plant, on yield, fruit weight and plant variables in seven varieties of saladette tomato produced under greenhouse and in hydroponics. The varieties evaluated were: Natalie, USATX 12227, USATX 9934, Juan Pablo, USATX 24019, USATX 16117, USATX 15538 , all established at a density of 31,250 plants or stems per hectare. Pruning at two stems per plant produced the highest yield in the USATX 16117, USATX 9934 and Natalie varieties, producing more than $2.3 \mathrm{~kg}$ per plant after six weeks of harvest. For the fruit weight, the USATX 9934 variety with two stems, was the one that produced fruits of greater caliber, being one of the three varieties with the highest yield. For the plant height, the USATX 24019 variety with one stem was the one with the highest height three months after the transplant.
\end{abstract}

Lycopersicon esculentum, Stem pruning, Yield

\section{Resumen}

El experimento se realizó de mayo a agosto del 2018 en la Universidad Tecnológica del Suroeste de Guanajuato (UTSOE) en un diseño en bloques completos al azar con tres repeticiones, en el invernadero 1 de $700 \mathrm{~m} 2$ de la Carrera de Agricultura Sustentable y Protegida; con la finalidad de evaluar el efecto de la poda a uno y dos tallos por planta, en el rendimiento, peso de fruto y variables de planta en siete variedades de jitomate saladette producidas bajo invernadero y en hidroponia. Las variedades evaluadas fueron: Natalie, USATX 12227, USATX 9934, Juan Pablo, USATX 24019, USATX 16117, USATX 15538, todas establecidas a una densidad de 31,250 plantas o tallos por hectárea. La poda a dos tallos por planta produjo el mayor rendimiento en las variedades USATX 16117, USATX 9934 y Natalie, al producir más de $2.3 \mathrm{~kg}$ por planta al cabo de seis semanas de cosecha. Para el peso de fruto, la variedad USATX 9934 a dos tallos, fue la que produjo frutos de mayor calibre, siendo una de las tres variedades con el mayor rendimiento. Para la altura de planta, la variedad USATX 24019 a un tallo fue la que presentó una mayor altura a los tres meses después del trasplante.

Lycopersicon esculentum, Poda de tallos, Rendimiento

Citation: VARGAS-ESPINOZA, Everardo, GAYTÁN-RUELAS, Marina, CALDERÓN-RUIZ, Alberto and MORALES FÉLIX, Verónica De Jesús. Production of seven varieties of tomato (Lycopersicon esculentum Mill.) pruned to one and two stems under greenhouse. Journal-Agrarian and Natural Resource Economics. 2019. 3-4: 19-24

\footnotetext{
* Correspondence to Author (email: evargase@ utsoe.edu.mx.)

$\dagger$ Researcher contributing as first author.
} 


\section{Introduction}

Recently, tomato production has increased by about 50 percent, driven by a larger agricultural area, with protected farming systems. Tomato availability is available in all months of the year (SRE, 2015). Mexico is the main exporter of fresh tomatoes worldwide, with about $20 \%$ of the volume and $25 \%$ of the value traded, which are mainly destined for the US. The country exports around 1.5 million tons per year, which represents between 50 and $70 \%$ of the production volume. In Mexico, about 52,374.91 ha of tomato are sown, with an average yield of 56.42 t.ha-1, making it the second most important vegetable in terms of planted area, the most transcendent in terms of volume in the national market and first for its production value (SIAP-SAGARPA, 2018).

In order to seek the transfer of technology to small producers; It was decided to implement this project to evaluate the effect of driving and handling one and two stems per plant on yield and yield components in seven commercial varieties of saladette tomatoes, under greenhouse conditions and hydroponic substrate, to compare and determine the best treatment after six weeks of harvest from two months after the transplant.

\section{Literature review}

The expression of crop yield potential depends on both its genetic constitution and environmental factors (climate, soil), biological factors and the production technique (Sánchez and Escalante, 1988); and that in turn this potential depends on the growth of the plant itself (Alcántar and Trejo, 2012), when considering all its plant organs as roots, branches, leaves, flowers, and of course the stem.

The functions of the stem of a plant are vital for its development. In general, stem functions are related to the structural support of the plant and the transport of nutrients. The structural support provided by the stem allows the leaves, fruits and flowers of the plant to be maintained so that they do not fall to the ground prematurely (Raven et al., 1992). The transport of compounds in the stem is of great importance as well.
This is due to a system of vascular tissues that connect with different parts of the plant and allow the transport of substances to and from the leaves, roots, flowers, fruits and the stem itself (Salisbury and Ross, 1994)

The stem of the tomato plant consists of an axis of 2 to $4 \mathrm{~cm}$ thick at its base, on which the leaves, secondary stems (simpoidal branching) and inflorescences develop. Its structure, from the outside in, consists of an epidermis, from which the glandular hairs leave towards the outside; a cortex or cortex, whose outermost cells are photosynthetic and the innermost are colenchymal; a vascular cylinder and spinal tissue. In the distal part is the apical meristem, where the new leaf and floral primordia begin (León, 2006).

Pruning is an indispensable practice for varieties of indeterminate growth produced in protected agriculture, which is carried out 15-20 days after transplantation with the appearance of the first lateral stems, which will be removed, as well as older leaves, thus improving aeration and facilitating different cultural tasks. Likewise, it helps determine in some commercial types of tomatoes, the number of arms or stems to leave per plant (Vera 2015, cited by Arébalo et al., 2018). Mendoza et al., (2018), in a study carried out to evaluate the effect of pruning one, two and three stems on tomato production, found that single-stemmed plants showed a higher yield, in addition to producing Large fruits in greater percentage.

In another study carried out by Arébalo et al., (2018), when evaluating the effect of pruning and management of tomato plants of the Ramsés variety with one and two stems, they found that despite not having statistically significant differences, the plants at a single stem they produced fruits with better quality indicators such as weight and size of the fruit, while the plants that were pruned in seedlings and after transplantation to form two stems, produced a greater amount of fruits, but of lower quality and therefore lower performance. Corella et al., (2013), when evaluating pruning of one and two stems in five indeterminate varieties of tomato, also found that, the yields in the plants pruned to two stems were much lower than those pruned to a stem. Outstanding in the performance in this case, the Moctezuma, Spartaco and Malinche varieties. 
According to Vera et al., (2015), pruning of two stems per plant allows to harvest a greater amount of medium-sized fruits and lower quality compared to plants that are not pruned. This effect is due to the high demand for nutrients that the plant requires in order to sustain two stems and produce fruits.

On the other hand and being equally important in this process, the nutritional balance plays a fundamental role to take into account from transplantation to the productive stage of the crop (León, 2006). Within the nutrition of the tomato crop, balanced growth, flowering and fruiting or fruit filling solutions can be made and applied, based on an optimum $\mathrm{pH}$ of 5.5 to 5.8 and a maximum electrical conductivity of 3.5 dS.m- ${ }^{1}$.

\section{Materials and methods}

\section{Project localization}

The present work was carried out from May to August 2018 at the Technological University of the Southwest of Guanajuato (UTSOE) in the $700 \mathrm{~m} 2$ greenhouse 1 of the Sustainable and Protected Agriculture Race, located on the Valle-Huanímaro Highway Km. 1.2 in Valle from Santiago, Gto., Mexico.

Plant material and planting density

Seven varieties of saladette tomatoes from the USAgriseeds commercial house were established in the greenhouse. The varieties evaluated were: Natalie, USATX 12227, USATX 9934, Juan Pablo, USATX 24019, USATX 16117, USATX 15538, all established at a density of 31,250 plants or stems per hectare, depending on pruning treatments.

\section{Experimental design and data analysis}

The experiment was established based on a randomized complete block design with three repetitions. A total of 14 treatments were evaluated, consisting of the combination of the seven indeterminate varieties of tomato with two pruning levels: one and two stems per plant; performing this last pruning a week after the transplant. The experimental unit for each treatment, consisted of three pots with river sand, each with a plant, either with one or two stems, depending on the treatments.
The data were analyzed using the SAS ${ }^{\circledR}$ statistical package version 9.3 to carry out the analysis of variance (ANOVA), a correlation between the evaluated variables and the Tukey means comparison test $(\mathrm{p} \leq 0.05)$.

\section{Variables evaluated}

Yield (kg / plant): It was obtained through the harvest of clusters in commercial maturity and weighed with the help of a digital analytical balance, obtaining a cumulative at the end of six weeks of harvest, from two months after transplant.

Fruit weight (g): It was obtained through the weekly harvest of all fruits in commercial maturity per plant, weighed with the help of an analytical balance and the average was obtained after six weeks of harvest.

Apex diameter (mm): It was obtained with the help of a digital vernier, measuring above the last well formed leaf for six weeks to finally obtain an average.

Plant height (m): It was obtained by measuring from the base of the stem to the apex with the help of a flexometer, the accumulated growth after three months after the transplant.

Number of leaves: The total of well-formed leaves was counted after three months after transplantation.

\section{Agronomic management}

Tutoreo of the plant was carried out starting at two weeks after the transplant, in addition to pruning leaves and axillary shoots weekly. Pollinations were done every day manually and with air. The lowering of the plant began once the plants reached two meters high.

As for the thinning of fruits, this work began when the first clusters of fruits appeared in the "marble" stage and as they appeared and developed consecutively on the plant, leaving a maximum of seven fruits per cluster.

Irrigation and crop nutrition were managed based on Steiner's solution taking an electrical conductivity that was $2.5 \mathrm{dS} / \mathrm{m}$ from the transplant stage, up to $3.0 \mathrm{dS} / \mathrm{m}$ at the production stage, with a $\mathrm{pH}$ of 5 to 6 , with fertilizer sources of macro and chemical micronutrients.

VARGAS-ESPINOZA, Everardo, GAYTÁN-RUELAS, Marina, CALDERÓN-RUIZ, Alberto and MORALES FÉLIX, Verónica De Jesús. Production of seven varieties of tomato (Lycopersicon esculentum Mill.) pruned to one and two stems under greenhouse. Journal-Agrarian and Natural Resource Economics. 2019 
Biweekly applications of amino acids, growth hormones and chelated micronutrients were also made.

The management of pests and diseases was carried out weekly or biweekly, beginning with periodic monitoring, implementation of cultural work and through the application of biological products based on fungi and bacteria, organic products based on botanical extracts, sulfur and copper; and low toxicological chemical pesticides.

\section{Results}

In the analysis of variance for the variables of yield and components of the same (Table 1), highly significant differences $(p \leq 0.01)$ were detected in the different treatments for the variables of yield, fruit weight and plant height, which supposes that the management of one and two stems, as well as the genetic potential of the varieties (Sánchez and Escalante, 1988), had an effect on these variables evaluated.

\begin{tabular}{|l|r|r|r|r|r|}
\hline FV & AP & \multicolumn{1}{l}{ DAP } & NHO & \multicolumn{1}{l|}{ PF } & \multicolumn{1}{l|}{ RTO } \\
\hline Trat & $0.050 * *$ & 0.1 & 7.32 & $433.2 * *$ & $0.941 * *$ \\
\hline Error & 0.009 & 0.074 & 5.133 & 52.51 & 0.077 \\
\hline CV $(\%)$ & 5.49 & 5.72 & 8.92 & 11.1 & 16.55 \\
\hline Mean & 1.754 & 4.75 & 25.3 & 65.27 & 1.67 \\
\hline
\end{tabular}

FV: Source of variation; Trat: Treatment; CV: Coefficient of variation; AP: Plant height; DAP: Apex diameter; NHO: Number of sheets; PF: Fruit weight; RTO: Performance. ${ }^{* *}$ Highly significant with $\mathrm{p} \leq 0.01$.

Table 1 Mean squares and level of statistical significance for the yield and plant variables in the stem pruning experiment in seven tomato varieties under greenhouse. Santiago Valley, Gto. 2018

The coefficients of variation were less than $20 \%$ for all the variables evaluated, which shows that there is reliability in the data.

The Tukey mean comparison test $(\mathrm{p} \leq$ 0.01 ) in Table 2, in which it was ordered based on the variable yield from highest to lowest; shows that for this variable, pruning and driving at two stems per plant produced the highest yield, with the USATX 16117, USATX 9934 and Natalie varieties being the best responders to this management, producing more than $2.3 \mathrm{~kg}$ per plant after six harvest weeks

These results are contrary to what was found by Mendoza et al., (2018), Arébalo et al., 2018 and by Corella et al., 2013), finding in previous works that varieties pruned to a stem were more yielding.
Regarding the weight of fruit (Table 2), the same USATX 9934 variety with two stems, produced fruits of greater caliber $(86.65 \mathrm{~g})$, thus affecting the yield (2.36 kg / plant); which demonstrates that it is an improved variety to adapt to these management conditions and to express its genetic potential; Although Villamán (2011) mentions that by leaving a second axis, it competes for nutrients, solar radiation and water, affecting the development of the first, which causes a delay in production, so it should be used when conditions environmental allow a longer period of growth.

As for the plant height (Table 2), it was found that the USATX 24019 variety with one stem was the one that grew the most with $2 \mathrm{~m}$ height and in counterpart, the variety that grew the least was USATX 9934 with $1.57 \mathrm{~m}$ led to two stems; This suggests that a plant with more than one stem must guarantee its optimum growth and development, reducing its vigor in height, as there is more competition for nutrients, solar radiation and water. However, this pattern of behavior was not proportional for all treatments, since not all varieties driven to two stems were those of lower height; then, rather, their behavior responds to the genetic potential as in some varieties of short internodes and to the adaptation of each of the varieties to these management conditions after three months after the transplant.

\begin{tabular}{|c|c|c|c|c|c|}
\hline $\begin{array}{l}\text { Treatment } \\
\text { (variety) }\end{array}$ & $\begin{array}{l}\text { Yield (kg } \\
\text { / plant) }\end{array}$ & $\begin{array}{l}\text { Fruit } \\
\text { Weight } \\
\text { (g) }\end{array}$ & $\begin{array}{l}\text { Plant } \\
\text { height } \\
(\mathbf{m})\end{array}$ & $\begin{array}{c}\text { Apex } \\
\text { diameter } \\
(\mathbf{m m})\end{array}$ & $\begin{array}{l}\text { Number } \\
\text { of sheets }\end{array}$ \\
\hline USATX $161172 \mathrm{~T}$ & $2.52 \mathrm{a}$ & $73.88 \mathrm{ab}$ & $1.84 \mathrm{abc}$ & $4.52 \mathrm{a}$ & $26.3 \mathrm{a}$ \\
\hline USATX $99342 \mathrm{~T}$ & $2.36 \mathrm{a}$ & $86.65 \mathrm{a}$ & $1.57 \mathrm{c}$ & $4.66 \mathrm{a}$ & $22.0 \mathrm{a}$ \\
\hline Natalie 2T & $2.32 \mathrm{a}$ & $73.45 \mathrm{ab}$ & $1.88 \mathrm{ab}$ & $4.54 \mathrm{a}$ & $24.3 \mathrm{a}$ \\
\hline USATX $122272 \mathrm{~T}$ & $2.26 \mathrm{ab}$ & $75.35 \mathrm{ab}$ & $1.70 \mathrm{bc}$ & $4.71 \mathrm{a}$ & $26.6 \mathrm{a}$ \\
\hline USATX $155382 \mathrm{~T}$ & $2.14 \mathrm{abc}$ & $65.61 \mathrm{abc}$ & $1.81 \mathrm{abc}$ & $4.69 \mathrm{a}$ & $25.6 \mathrm{a}$ \\
\hline Juan Pablo 2T & $2.0 \mathrm{abcd}$ & $55.64 \mathrm{bcd}$ & $1.82 \mathrm{abc}$ & $4.69 \mathrm{a}$ & $25.3 \mathrm{a}$ \\
\hline USATX $155381 T$ & $1.43 \mathrm{bcde}$ & $68.66 \mathrm{ab}$ & $1.61 \mathrm{bc}$ & $4.72 \mathrm{a}$ & $25.3 \mathrm{a}$ \\
\hline USATX 12227 1T & $1.40 \mathrm{cde}$ & $71.15 \mathrm{ab}$ & $1.63 \mathrm{bc}$ & $4.94 \mathrm{a}$ & $25.3 \mathrm{a}$ \\
\hline USATX $240192 \mathrm{~T}$ & $1.35 \mathrm{cde}$ & $46.06 \mathrm{~cd}$ & $1.69 \mathrm{bc}$ & $5.18 \mathrm{a}$ & $24.6 \mathrm{a}$ \\
\hline USATX 16117 1T & $1.25 \mathrm{de}$ & $60.82 \mathrm{bcd}$ & $1.79 \mathrm{abc}$ & $4.73 \mathrm{a}$ & $26.3 \mathrm{a}$ \\
\hline Juan Pablo 1T & $1.23 \mathrm{de}$ & $60.17 \mathrm{bcd}$ & $1.61 \mathrm{bc}$ & $5.03 \mathrm{a}$ & $26.0 \mathrm{a}$ \\
\hline USATX $99341 \mathrm{~T}$ & $1.18 \mathrm{de}$ & $69.55 \mathrm{ab}$ & $1.68 \mathrm{bc}$ & $4-64 \mathrm{a}$ & $23.0 \mathrm{a}$ \\
\hline Natalie 1T & $1.14 \mathrm{e}$ & $66.18 \mathrm{abc}$ & $1.89 \mathrm{ab}$ & $4.69 \mathrm{a}$ & $26.0 \mathrm{a}$ \\
\hline USATX 24019 1T & $0.86 \mathrm{e}$ & $40.68 \mathrm{~d}$ & $2.0 \mathrm{a}$ & $4.82 \mathrm{a}$ & $28.3 \mathrm{a}$ \\
\hline Media & 1.67 & 65.27 & 1.754 & 4.75 & 25.3 \\
\hline DSM & 0.836 & 21.8 & 0.29 & 0.819 & 6.81 \\
\hline
\end{tabular}

T: Stems; DSM: Minimum significant difference; Are means with equal letters within the same column statistically equal (Tukey $\alpha \leq 0.05$ ).

Table 2 Comparison of means for the yield and plant variables, in the stem pruning experiment in seven tomato varieties under greenhouse. Santiago Valley, Gto. 2018 
In the correlation test (Table 3), the experiment showed highly positive or direct correlation ( $p \leq 0.01)$ between the variables number of leaves with plant height, which demonstrates that for some varieties the more they grew, they managed to develop more leaves, as found for the highest-rise variety USATX 24019 (Table 2), responding to the genetics of the variety.

A highly positive correlation was also found between fruit weight and yield, which shows that yield is favored when larger fruits are developed and harvested, as presented with the USATX 9934 variety with two stems (Table 2).

\begin{tabular}{|l|r|r|r|c|}
\hline & \multicolumn{1}{|c}{ AP } & \multicolumn{1}{c|}{ DAP } & \multicolumn{1}{c|}{ NHO } & PF \\
\hline DAP & -0.251 & & & \\
\hline NHO & $0.540^{* *}$ & 0.056 & & \\
\hline PF & $-0.36^{*}$ & -0.263 & -0.168 & \\
\hline RTO & -0.059 & -0.31 & -0.07 & $0.571^{* *}$ \\
\hline
\end{tabular}

DAP: Apex diameter; AP: Plant height; NHO: Number of sheets; PF: Fruit weight; RTO: Performance. *: Significant with $\alpha \leq 0.05$; **: Significant with $\alpha \leq 0.01$.

Table 3 Correlation coefficients between the variables evaluated in the stem pruning experiment in seven tomato varieties under greenhouse. Santiago Valley, Gto. 2018

The indirect or negative correlation $(\mathrm{p} \leq$ 0.05 ) between plant height and fruit weight (Table 3), responds to the fact that some more growing varieties produced smaller fruits, as found for the USATX 24019 variety on a stem; which probably needs more time to develop height and leaf vigor, being a very vegetative variety, until some time when it is adapted to environmental conditions (Villamán, 2011), to start expressing its productive potential.

\section{Conclusions}

Pruning and driving at two stems per plant produced the highest yield in the USATX 16117, USATX 9934 and Natalie varieties, producing more than $2.3 \mathrm{~kg}$ per plant after six weeks of harvest.

Regarding the weight of the fruit, it was the USATX 9934 variety, which led to two stems, which produced fruits of greater caliber, being also one of the three varieties with the highest performance statistically.
For the plant height, the USATX 24019 variety led to a stem was the one with the highest height three months after the transplant; however, not all varieties driven to a stem were those of greater height.

Pruning at one and two stems had no effect on apex diameter and number of leaves, which simply allowed us to observe the expression of the natural genetic potential of the seven varieties under these production conditions..

\section{References}

Alcántar G. G.; Trejo T. L. 2012. Nutrición de cultivos. Ed. BBA. México. 454 p.

Arébalo M. M.; Mérida R. J.; Escalante G. J.; Yáñez C. J.; Osorio H. E. 2018. Efecto de podas tempranas en tomate (Solanum lycopersicum) var. Ramsés para la formación de plantas con dos tallos. Agroproductividad. 11(10):57-61

Corella B. R.; Soto O. R.; Escoboza G. F.; Grimaldo J. O.; Huez L. M.; Ortega N. M. 2013. Comparación de dos tipos de poda en tomate (Lycopersicon esculentum Mill.), sobre el rendimiento en invernadero. www.agricultura.uson.mx , publicaciones , congresos. Consultado (agosto de 2013).

León, G. H. M. 2006. Guía para el cultivo de tomate en invernadero. Segunda edición. Editorial SEP-INDAUTOR. 263 p. Chihuahua, Chih.

Mendoza P. C.; Ramírez A. C.; Martínez R. A.; Rubiños P. J.; Trejo C.; Vargas O. A. 2018. Efecto de número de tallos en la producción y calidad de jitomate cultivado en invernadero. Revista Mexicana de Ciencias Agrícolas. 9(2): 355-366

Raven P.; Evert R.; Eichhorn S. 1992. Biology of Plants. Worth Publishers Inc. New York. 4 ed.

Salisbury B. F.; C. W. Ross. 1994. Fisiología Vegetal. Editorial Iberoamericana. México. 759 p.

Sánchez Del C. F.; E. Escalante, R. 1988. Hidroponía. Tercera edición. Universidad Autónoma Chapingo. Chapingo, México. Pp. 17 y 18. 
Secretaría de Relacione Exteriores. 2015. México: Primer Exportador Mundial de Tomate.

Recuperado

de:

http://consulmex.sre.gob.mx/omaha/images/JIT

OMATE/jitomate.pdf

\begin{abstract}
SIAP-SAGARPA. 2018. Producción agrícola por cultivo. http://infosiap.siap.gob.mx/aagricola_siap/iculti vo/index.jsp. Consultado (agosto de 2018).
\end{abstract}

Vera D. H. E.; Vera B. C. G.; Bello I. P. 2015. Efecto de poda de tallo en el rendimiento del híbrido de tomate Miramar F1. Revista ESPAMCIENCIA 6:71-75

Villamán M. A. 2011. Efecto de tres tipos de poda sobre el rendimiento y calidad de tomate (Lycopersicum esculentum) para producción en la provincia de Cautin, Chile. Universidad de la Frontera-Facultad de Ciencia Agropecuaria y Forestal. 